\title{
Erratum
}

\section{Regional self-reliance for livestock feed, meat, dairy and eggs in the Northeast USA - ERRATUM}

\author{
Zach Conrad, Nicole E. Tichenor, Christian J. Peters and Timothy S. Griffin
}

doi: 10.1017/S1742170516000089, Published online by Cambridge University Press, 4 April 2016

The following errors have been noted in the above mentioned article. The publisher regrets this error and sincerely apologises for any inconvenience caused:

On page 6, in Table 1, column heading 'Regional total (103 ha)'

Should Read:

'Regional total $\left(10^{3}\right.$ ha)'

On Page 7, in Table 2, under headings TDN and Crude protein column heading 'Regional total (106 kg)',

Should Read:

'Regional total $\left(10^{6} \mathrm{~kg}\right)$ ',

And, in Table 3, column headings 'Total live weight (106 kg)' and 'Feed demand (106 kg)'

Should Read:

'Total live weight $\left(10^{6} \mathrm{~kg}\right)$ ' and 'Feed demand $\left(10^{6} \mathrm{~kg}\right)$ '

\section{Reference}

Zach Conrad, Nicole E. Tichenor, Christian J. Peters and Timothy S. Griffin. Regional self-reliance for livestock feed, meat, dairy and eggs in the Northeast USA. Renewable Agriculture and Food Systems, available on CJO2016. doi:10.1017/S1742170516000089. 